\title{
PENGARUH FASILITAS, PENEMPATAN KERJA DAN KOMITMEN TERHADAP KINERJA PEGAWAI DINAS PANGAN DAN PERTANIAN KOTA TANJUNGBALAI
}

\author{
${ }^{1}$ Erlinda Hayani, ${ }^{2}$ Suparna, ${ }^{3}$ Fajar Oza Pratama, ${ }^{4}$ Sari Quratul Ainy, ${ }^{5}$ Erwin. \\ $1,2,3,4,5$ Universitas Islam Sumatera Utara \\ 1erlinda.hayani@gmail.com, ${ }^{2}$ suparna.mm@gmail.com, ${ }_{5}^{3}$ fazar.oza@gmail.com, ${ }_{5}$ sari.ainy@gmail.com, \\ 5erwinmm@gmail.com
}

\begin{abstract}
The formulation of the problem in this study are: How the effect of facilities, job placement and commitment to the performance of the employees at Dinas Pangan Dan Pertanian Kota Tanjungbalai. This study aims to determine the effect of facilities, job placement and commitment to employee performance. The sample in this study were 38 people. The results showed; Facility variable partially has a positive effect on employee performance; Job placement variables partially have a positive effect on employee performance; The commitment variable partially has a positive effect on employee performance; Facility variables, work placement and commitment simultaneously have a positive and significant effect on employee performance.
\end{abstract}

Keywords : Amenities; Work Placement; Commitment; Employee Performance

ABSTRAK : Rumusan masalah dalam penelitian ini adalah : Bagaimana pengaruh fasilitas, penempatan kerja dan komitmen terhadap kinerja pegawai Dinas Pangan Dan Pertanian Kota Tanjungbalai. Penelitian ini bertujuan untuk mengetahui pengaruh fasilitas, penempatan kerja dan komitmen terhadap kinerja pegawai. Sampel dalam penelitian ini sebanyak 38 orang. Hasil penelitian menunjukkan; Variabel fasilitas secara parsial berpengaruh positif terhadap kinerja pegawai; Variabel penempatan kerja secara parsial berpengaruh positif terhadap kinerja pegawai; Variabel komitmen secara parsial berpengaruh positif terhadap kinerja pegawai; Variabel fasilitas, penempatan kerja dan komitmen secara simultan memiliki pengaruh yang positif dan signifikan terhadap kinerja pegawai.

Kata Kunci : Fasilitas; Penempatan Kerja; Komitmen; Kinerja Pegawai

\section{Pendahuluan}

Organisasi merupakan suatu kumpulan orang-orang yang saling bekerjasama dengan memanfaatkan fasilitas yang ada untuk mencapai tujuan yang telah direncanakan. Organisasi dan pegawai merupakan dua hal yang saling membutuhkan, jika pegawai berhasil membawa kemajuan bagi instansi, keuntungan yang diperoleh akan dipetik oleh kedua belah pihak. Bagi pegawai, keberhasilan merupakan aktualisasi diri sekaligus peluang untuk memenuhi kebutuhan hidupnya. Sedangkan bagi organisasi atau instansi, keberhasilan merupakan sarana menuju pertumbuhan dan perkembangan organisasi itu sendiri. Pegawai memiliki peran yang besar dalam kesuksesan instansi. Tolak ukur keberhasilan suatu instansi dapat dilihat dari kinerja pegawai.
Kinerja pegawai berarti produktifitas dan output pegawai sebagai hasil dari pengembangan pegawai, dan akhirnya mempengaruhi efektivitas instansi (Hammed dan Waheed 2011:228). Organisasi atau instansi dituntut untuk selalu meningkatkan kinerja pegawai agar instansi atau instansi dapat terus berkembang. Karena dengan adanya peningkatan kinerja dalam diri pegawai, maka pegawai mampu mengoptimalkan kemampuan untuk melakukan pekerjaannya. Kinerja pegawai yang maksimal merupakan aset yang tak ternilai bagi organisasi atau instansi, maka dari itu setiap organisasi akan selalu berusaha untuk meningkatkan kinerja pegawai dengan harapan apa yang menjadi tujuan organisasi atau instansi akan tercapai. 
Kinerja pegawai yang baik dapat dicapai melalui penanaman komitmen organisasi yang kuat dalam diri pegawai dan penempatan kerja pegawai yang cocok dengan potensi pegawai. Komitmen organisasi menentukan berhasil atau tidaknya tujuan yang ingin dicapai oleh organisasi atau instansi. Dengan adanya komitmen pegawai terhadap suatu organisasi atau instansi, dapat membuat pegawai tersebut memiliki rasa tanggung-jawab yang besar dan bersedia memberikan segala kemampuannya, sehingga timbul rasa memiliki terhadap organisasi atau instansi tempat ia bekerja. Sebab komitmen pegawai yang tinggi terhadap organisasi memungkinkan seseorang pegawai memperlihatkan keinginan yang kuat untuk tetap menjadi anggota organisasi atau instansi, kemudian pegawai tersebut bersedia untuk berusaha sebaik mungkin demi kepentingan organisasi tersebut serta tingkat kepercayaan yang tinggi akan tujuan dan nilai-nilai organisasi atau instansi yang melekat pada dirinya. Keberhasilan suatu organisasi akan berdampak pada kelangsungan hidup organisasi dan pegawainya.

Dengan demikian, apabila masing-masing pegawai dalam organisasi atau instansi memiliki komitmen yang tinggi terhadap organisasi, maka besar kemungkinan kesuksesan dapat tercapai dan sebaliknya, apabila masing-masing pegawai tidak memiliki komitmen yang tinggi atau komitmen yang rendah, maka besar kemungkinan kesuksesan tidak dapat tercapai secara maksimal. Komitmen organisasi tidak hanya berpatokan pada tanggung-jawab dan loyalitas pegawai terhadap organisasi atau instansinya, namun bagaimana pegawai merasa aman dan nyaman ketika menjadi bagian dalam organisasi yang ditempati. Komitmen organisasi terdiri dari komitmen pegawai terhadap organisasi dan komitmen organisasi terhadap pegawai.

Komitmen memiliki peranan penting terutama pada kinerja seseorang ketika bekerja. Hal ini disebabkan oleh adanya komitmen yang menjadi acuan serta dorongan yang membuat mereka lebih bertanggungjawab terhadap kewajibannya. Dengan kata lain, hal ini dapat dianggap sebuah pola pikir dimana pegawai memikirkan sejauh mana nilai dan tujuannya sendiri sesuai dengan tujuan organisasi atau instansi tempat ia bekerja. Adanya kesesuaian antara nilai dan tujuan pegawai dengan organisasi akan menumbuhkan komitmen yang kuat dalam diri pegawai dalam bekerja di organisasi sehingga menyebabkan terjadinya tingkah laku pegawai yang sesuai dengan harapan organisasi. Maka untuk membangkitkan komitmen pegawai tersebut, organisasi harus memperhatikan faktor-faktor yang mempengaruhi komitmen berorganisasi yaitu: karakteristikorganisasi menyangkut kebijakan dan aturan dalam organisasi atau instansi, karakteristik individu menyangkut tentang kebutuhan berprestasi pegawai serta pengalaman kerja pegawai menyangkut tentang motivasi dan cara kerja pegawai. Instansi penting memperhatikan faktor-faktor komitmen organisasi, dimaksudkan agar instansi selalu dapat menumbuhkan dan membina kepercayaan pegawai terhadap organisasi atau instansi. Sementara masalah yang berkaitan dengan komitmen organsisasi adalah kurangnya rasa ikut memiliki (sense of belonging) pegawai terhadap organisasi.

Menurut Soekidjan (2009:56), keterlibatan pegawai dalam suatu organisasi menunjukkan kuatnya keinginan seseorang untuk terus bekerja bagi suatu organisasi atau instansi. Menurut keadaan yang diamati oleh penulis ketika penulis melakukan survey awal pada Dinas Pangan Dan Pertanian Kota Tanjungbalai, bahwa pegawai tidak bekerja keras melakukan tugas dan tanggung- jawab yang diembankan. Hal ini terlihat ketika pegawai Dinas Pangan Dan Pertanian Kota Tanjungbalai melakukan penyisiran pada Sensus Pangan dan Pertanian (SPP2016). Pegawai kurang menikmati tugasnya ketika harus turun kelapangan melakukan pendataan, sehingga ada beberapa dari pegawai yang melakukan laporan pendataan palsu. Selain itu, setiap pegawai pada jam kerja, banyak yang tidak bekerja bahkan tidak berada dikantor selama jam kerja. Dan kembali kekantor ketika waktu sudah mendekati jam pulang kantor.

Penempatan kerja juga menentukan berhasil atau tidaknya tujuan yang ingin dicapai oleh organisasi atau instansi. Dalam mewujudkan eksistensinya, organisasi atau instansi memerlukan sejumlah pegawai yang terarah padapencapaian tujuan yang telah ditetapkan. Penempatan pegawai yang memenuhi kualifikasi dan didukung dengan organisasi yang berkualitas, akan 
menjadikan organisasi atau instansi tersebut memiliki daya kompetitif yang tinggi.

Penempatan pegawai itu sendiri dimulai kegiatan rekrutmen dan seleksi. Aktivitas rekrutmen dan seleksi yang berkualitas akan menunjukkan orang yang terbaik untuk jabatan yang tersedia dan memastikan orang tersebut ditempatkan pada posisi yang tepat. Pada dasarnya, penempatan merupakan pengisian jabatan yang kosong agar tugas pokok pada jabatan tersebut dapat dilaksanakan dengan baik. Pegawai yang ditempatkan sesuai pada bidang kemampuannya dapat memicu kinerjanya dalam bekerja dan meningkatkan ketrampilannya. Keberhasilan dalam melakukan penempatan tenaga kerja akan banyak mempengaruhi langkah selanjutnya dalam proses pencapaian tujuan organisasi atau instansi. Dengan kata lain, pegawai yang ditempatkan tersebut memiliki kemampuan untuk dapat melaksanakan pekerjaannya pada suatu jabatan secara efektif dan efisien sehingga diharapkan menghasilkan pegawai yang berprestasi demi mewujudkan misi organisasi atau instansi.

Penempatan harus didasarkan pada job description dan job specification yang telah ditentukan serta berpedoman kepada prinsip "The right man on the right place and the right man behind the job". Hal ini akan membawa suatu instansi kepada hasil kerja yang optimal karena terdapat adanya korelasi positif antara penempatan pegawai dengan peningkatan produktifitas kerja. (Hasibuan,2015:63) Sejalan dengan keadaan yang diamati oleh penulis ketika penulis melakukan survey awal pada Dinas Pangan Dan Pertanian Kota Tanjungbalai tersebut, bahwa penempatan kerja terjadi yaitu seperti pada saat belum habis periode sudah mengalami pemindahan tempat karena dipromosikan dengan alasan kinerja yang sangat baik.

Dinas Pangan Dan Pertanian Kota Tanjungbalai merupakan lembaga pemerintahan departemen yang berada dibawah dan bertanggung jawab langsung kepada walikota. Dinas Pangan Dan Pertanian Kota Tanjungbalai mempunyai tugas Pemerintahan di bidang kegiatan pangan dan pertanian sesuai dengan ketentuan Peraturan Perundangundangan yang berlaku. Salah satu misi dari Dinas Pangan Dan Pertanian Kota Tanjungbalai adalah menciptakan lembaga pangan yang kompeten dan profesional, didukung pemanfaatan teknologi informasi mutakhir untuk kemajuan perstatistikan Indonesia.

Pegawai akan memiliki komitmen yang tinggi sejalan dengan penempatan kerja yang cocok dengan kompetensi yang dimilikinya, dan hal ini akan mengantarkan pegawai tersebut dalam menghasilkan kinerja yang maksimal yang diharapkan oleh organisasi atau instansi tempat ia bekerja. Komitmen organisasi dan penempatan kerja adalah kedua hal yang sangat berpengaruh pada kepuasan kerja pegawai yang pada akhirnya, akan sangat menunjang kinerja pegawai.

\subsection{Rumusan Masalah}

Berdasarkan latar belakang masalah tersebut diatas, maka yang menjadi rumusan masalah dalam penelitian ini adalah :

a. Bagaimana pengaruh fasilitas terhadap kinerja pegawai Dinas Pangan Dan Pertanian Kota Tanjungbalai?

b. Bagaimana pengaruh penempatan kerja terhadap kinerja pegawai Dinas Pangan Dan Pertanian Kota Tanjungbalai?

c. Bagaimana pengaruh komitmen terhadap kinerja pegawai Dinas Pangan Dan Pertanian Kota Tanjungbalai?

d. Bagaimana pengaruh fasilitas, penempatan kerja dan komitmen terhadap kinerja pegawai Dinas Pangan Dan Pertanian Kota Tanjungbalai?

\subsection{Batasan Masalah}

Agar masalah yang diteliti tidak meluas dan menghindari kesimpangsiuran atau kesalahan persepsi serta mengingat keterbatasan penulis, maka perlu dilakukan pembatasan masalah. Pembatasan masalah sangatlah penting untuk menentukan fokus penelitian. Untuk itu, maka permasalahan pada penelitian ini dibatasi pada pengaruh fasilitas, penempatan kerja dan komitmen terhadap kinerja pegawai Dinas Pangan Dan Pertanian Kota Tanjungbalai.

\subsection{Hioptesis}

Berdasarkan perumusan masalah dan kerangka pemikiran diatas, maka hipotesis dalam penelitian ini adalah sebagai berikut :

a. Fasilitas berpengaruh terhadap kinerja pegawai Dinas Pangan Dan Pertanian Kota Tanjungbalai 
b. Penempatan kerja berpengaruh terhadap kinerja pegawai Dinas Pangan Dan Pertanian Kota Tanjungbalai

c. Komitmen berpengaruh terhadap kinerja pegawai Dinas Pangan Dan Pertanian Kota Tanjungbalai

d. Fasilitas, penempatan kerja dan komitmen berpengaruh secara simultan terhadap kinerja pegawai Dinas Pangan Dan Pertanian Kota Tanjungbalai

\subsection{Tujuan Penelitian}

Berdasarkan rumusan masalah penelitian sebagaimana diuraikan di atas, maka tujuan yang hendak dicapai dalam penelitian ini yaitu:

a. Untuk mengetahui seberapa besar pengaruh fasilitas terhadap kinerja pegawai Dinas Pangan Dan Pertanian Kota Tanjungbalai?

b. Untuk mengetahui seberapa besar pengaruh penempatan kerja terhadap kinerja pegawai Dinas Pangan Dan Pertanian Kota Tanjungbalai?

c. Untuk mengetahui seberapa besar pengaruh komitmen terhadap kinerja pegawai\ Dinas Pangan Dan Pertanian Kota Tanjungbalai?

d. Untuk mengetahui seberapa besar pengaruh fasilitas, penempatan kerja dan komitmen terhadap kinerja pega

\section{Metode Penelitian}

\subsection{Populasi}

Sugiyono, (2013: 90) mengemukakan bahwa populasi adalah wilayah generalisasi yang terdiri atas subjek/objek yang mempunyai kualitas dan karakteristik tertentu yang ditetapkan oleh peneliti untuk dipelajari dan kemudian ditarik kesimpulannya.

Dalam penelitian ini yang menjadi populasi penelitian adalah pegawai Dinas
Pangan dan Pertanian Kota Tanjungbalai dengan jumlah 40 orang.

Tabel 1 Kerangka Populasi Berdasarkan Jabatan Thn. 2020

\begin{tabular}{|c|c|c|}
\hline No. & Jabatan & Jlh.Populasi \\
\hline 1 & Kepala Dinas & 1 \\
\hline 2 & Sekretaris & 1 \\
\hline 3 & Kepala Bidang & 4 \\
\hline 4 & Kepala Seksi & 9 \\
\hline 5 & Kepala Sub Bagian & 3 \\
\hline 6 & Kepala UPTD & 4 \\
\hline 7 & Bendahara & 2 \\
\hline 8 & Seksi & 2 \\
\hline 9 & Pengadmin & 6 \\
\hline 10 & Pengelola & 5 \\
\hline 11 & Penyuluh & 3 \\
\hline 12 & Jumlah & 40 \\
\hline
\end{tabular}
2020

\subsection{Sampel}

Sampel adalah bagian dari jumlah dan karakteristik yang dimiliki oleh populasi tersebut. Bila populasi besar, dan peneliti tidak mungkin mempelajari semua yang ada pada populasi, misalnya karena keterbatasan dana, tenaga dan waktu, maka peneliti dapat menggunakan sampel yang diambil dari populasi itu. Apa yang dipelajari dari sampel itu, kesimpulan akan dilakukan untuk populasi. Untuk itu sampel yang diambil dari populasi harus betul-betul representative (mewakili). Untuk mencari jumlah sampel dapat menggunakan teknik slovin. (Sugiyono, 2013:116).

Dalam penelitian ini digunakan sampel dari seluruh populasi dengan jumlah 38 responden di karenakan Kepala Dinas dan Kepala Seksi sebagai peneliti tidak ikut dijadikan sampel dalam penelitian ini.

Tabel 2. Kerangka Distribusi Sampel Berdasarkan Jabatan Thn. 2020

\begin{tabular}{|c|l|c|c|c|}
\hline No & \multicolumn{1}{|c|}{ Jabatan } & Jlh Populasi & Jlh Sampel & Keterangan \\
\hline 1 & Kepala Dinas & 1 & - & Tidak diteliti \\
\hline 2 & Sekretaris & 1 & 1 & Diteliti \\
\hline 3 & Kepala Bidang & 4 & 4 & Diteliti \\
\hline 4 & Kepala Seksi & 9 & 8 & 1 Orang Peneliti \\
\hline 5 & Kepala Sub Bagian & 3 & 3 & Diteliti \\
\hline 6 & Kepala UPTD & 4 & 4 & Diteliti \\
\hline 7 & Bendahara & 2 & 2 & Diteliti \\
\hline 8 & Seksi & 2 & 2 & Diteliti \\
\hline 9 & Pengadmin & 6 & 6 & Diteliti \\
\hline
\end{tabular}




\begin{tabular}{|c|l|c|c|c|}
\hline No & \multicolumn{1}{|c|}{ Jabatan } & Jlh Populasi & Jlh Sampel & Keterangan \\
\hline 10 & Pengelola & 5 & 5 & Diteliti \\
\hline 11 & Penyuluh & 3 & 3 & Diteliti \\
\hline & Jumlah & $\mathbf{4 0}$ & $\mathbf{3 8}$ & \\
\hline
\end{tabular}

Sumber: Dinas Pangan dan Pertanian Kota Tanjungbalai - 2020

\subsection{Uji Normalitas}

Pengujian normalitas data bertujuan untuk melihat normal tidaknya sebaran data yang akan dianalisis. Model regresi yang baik adalah distribusi normal atau mendekati normal. Untuk melihat normalitas data ini digunakan pendekatan grafik yaitu Normality Probability Plot.

Deteksi normalitas dengan melihat penyebaran data (titik) pada sumbu diagonal dari grafik. Menurut Santoso (2014:214), dasar pengambilan keputusan adalah:

a. Jika data menyebar disekitar garis diagonal dan mengikuti arah garis diagonal, maka model regresi memenuhi asumsi normalitas.

b. Jika data menyebar jauh dari garis diagonal dan atau tidak mengikuti arah garis diagonal, maka model regresi tidak memenuhi asumsi normalitas. Pada output SPSS versi 24.00 bagian normal $P-P$ Plot of Regresion Standardized Residual, dapat dijelaskan bahwa data-data (titiktitik) cenderung lurus mengikuti garis diagonal sehingga data dalam penelitian ini cenderung berdistribusi normal, seperti terlihat pada gambar dibawah ini.

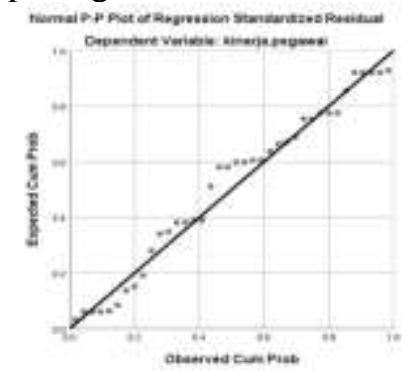

Gambar 1. Normalitas Data

\subsection{Uji Multikolinearitas}

Pengujian multikolinearitas dilakukan untuk melihat apakah pada model regresi ditemukan adanya korelasi antara variabel bebas. Jika terjadi korelasi, maka dinamakan terdapat problem multikolinearitas. Cara mendeteksinya adalah dengan melihat nilai Variance Inflation Factor (VIF). Menurut Santoso (2014:203), pada umumnya jika VIF lebih besar dari 5, maka variabel bebas tersebut multikolinearitas dengan variabel bebas lainnya.

Pada ouput SPSS bagian Coefficient, semua angka VIF berada dibawah 5, hal ini menunjukan tidak terjadi multikolinearitas, seperti dapat dilihat pada tabel dibawah ini.

Tabel 3. Uji Multikolinearitas

\begin{tabular}{|l|l|r|r|}
\hline \multicolumn{3}{|c|}{ Coefficients $^{\mathbf{a}}$} \\
\hline \multicolumn{2}{|l|}{ Model } & \multicolumn{2}{|c|}{$\begin{array}{c}\text { Collinearity } \\
\text { Statistics }\end{array}$} \\
\cline { 2 - 4 } & & Tolerance & VIF \\
\hline \multirow{2}{*}{1} & (Constant) & & \\
\cline { 2 - 4 } & fasilitas & .741 & 1.350 \\
\cline { 2 - 4 } & penempatan.kerja & .711 & 1.407 \\
\cline { 2 - 4 } & komitmen & .643 & 1.555 \\
\hline
\end{tabular}

a. Dependent Variable: kinerja.pegawai

Sumber: Out Put SPSS Data Diolah-2020

\subsection{Uji Heteroskedastisitas}

Pengujian heteroskedastisitas bertujuan untuk melihat apakah dalam sebuah model regresi terjadi ketidaksamaan varians dari residual yang merupakan suatu pengamatan ke pengamatan yang lainnya. Jika varians dari residual yang merupakan suatu pengamatan ke pengamatan yang lain bernilai tetap, maka hasil data disebut homoskedastisitas dan jika varians berbeda atau bernilai tidak tetap maka disebut heteroskedastisitas. Model regresi yang baik adalah model yang bernilai tetap atau homoskedastisitas atau tidak terjadi heteroskedastisitas.

Deteksi heteroskedastisitas dilakukan dengan cara melihat ada tidaknya pola tertentu pada data yang diolah. Menurut Santoso (2014:208), dasar pengambilan keputusannya adalah:

a. Jika pola tertentu seperti titik-titik yang ada membentuk suatu pola tertentu yang teratur, maka terdapat situasi heteroskedastisitas.

b. Jika tidak ada pola yang jelas, serta titiktitik menyebar diatas dan dibawah angka nol pada sumbu Y, maka tidak terjadi heteroskedastisitas.

Pada output SPSS dibagian Scatrerplot, terlihat titk-titik menyebar secara acak, tidak 
membentuk sebuah pola tertentu yang jelas, serta tersebar baik diatas maupun dibawah angka nol pada sumbu Y. Hal ini berarti tidak terjadi heterskedastisitas pada model regresi, sehingga model regresi layak dipakai. Pola Scatterplot dapat dilihat pada gambar dibawah ini.

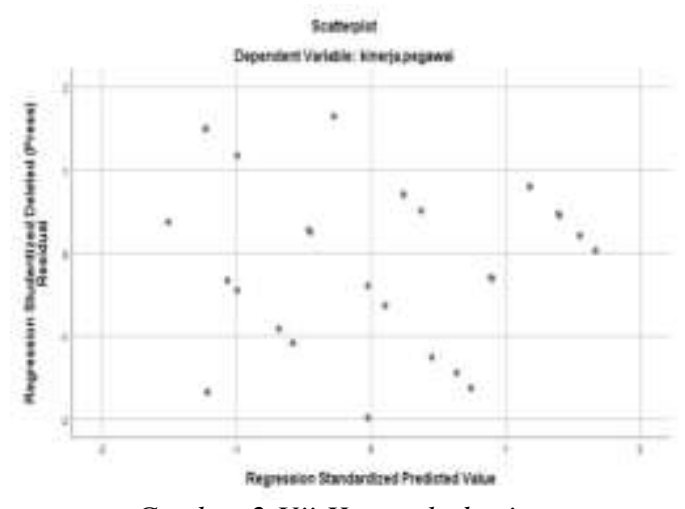

Gambar 2 Uji Heteroskedastitas

Tabel 4. Hasil Uji Statistik Keofesien Regresi

\begin{tabular}{|c|c|c|c|c|c|c|}
\hline \multicolumn{7}{|c|}{ Coefficients $^{\mathrm{a}}$} \\
\hline \multirow{2}{*}{\multicolumn{2}{|c|}{ Model }} & \multicolumn{2}{|c|}{$\begin{array}{c}\text { Unstandardized } \\
\text { Coefficients }\end{array}$} & \multirow{2}{*}{$\begin{array}{c}\begin{array}{c}\text { Standardize } \\
\text { Coefficients }\end{array} \\
\text { Beta }\end{array}$} & \multirow[t]{2}{*}{$\mathrm{t}$} & \multirow[t]{2}{*}{ Sig. } \\
\hline & & B & Std. Error & & & \\
\hline \multirow{4}{*}{1} & (Constant) & 5.297 & 4.515 & & 1.173 & .249 \\
\hline & fasilitas & .388 & .102 & .408 & 3.797 & .001 \\
\hline & penempatan.kerja & .270 & .092 & .320 & 2.916 & .006 \\
\hline & komitmen & .282 & .100 & .324 & 2.808 & .008 \\
\hline
\end{tabular}

a. Dependent Variable: kinerja.pegawai

Berdasarkan tabel 4 diatas dapat dibuat persamaan regresi sebagai berikut: $\mathrm{Y}=\mathrm{a}+$ $\mathrm{b} 1 \mathrm{X} 1+\mathrm{b} 2 \mathrm{X} 2+\mathrm{b} 3 \mathrm{X} 3+\varepsilon$

$\mathrm{Y}=5,297+0,388 X_{1}+0,270 X_{2}+0,282 X_{3}+$ $\varepsilon$

Persamaan diatas dijelaskan bahwa koefesien fasilitas bernilai positif yaitu 0,388, dengan demikian bahwa variabel fasilitas memiliki pengaruh yang positif terhadap kinerja pegawai.

Berdasarkan persamaan diatas bahwa koefesien penempatan kerja bernilai positif yaitu 0,270. Dengan demikian bahwa variabel

\section{Evaluasi Data ( Analisa Regresi Linier Berganda ) \\ 3.1 Pengujian Hipotesis}

Dalam evaluasi data ini penulis akan melakukan pengujian hipotesis, baik secara partial ataupun secara simultan. Selanjutnya untuk mempermudah dalam evaluasi data ini, maka penulis mencari niali-nilai yang dibutuhkan dengan menggunakan perangkat lunak komputer yaitu program SPSS V.24.00 for windows dengan hasil data sebagai berikut: penempatan kerja mempunyai pengaruh positif terhadap kinerja pegawai.

Berdasarkan persamaan diatas bahwa koefesien komitmen bernilai positif yaitu 0,282 . Dengan demikian bahwa variabel komitmen juga mempunyai pengaruh positif terhadap kinerja pegawai.

\subsection{Pengujian Secara Simultan (Uji F)}

Untuk melihat hasil seberapa besar pengaruh yang di berikan variabel independen terhadap dependen secara simultan ( bersamasama ) pada penelitian ini maka dapat di jelaskan pada tabel di bawah ini :

Tabel 5. Hasil Uji Statistik Secara Simultan

\begin{tabular}{|l|l|r|r|r|r|r|}
\hline \multicolumn{7}{|c|}{ ANOVA $^{\mathrm{a}}$} \\
\hline \multicolumn{1}{|c|}{ Model } & $\begin{array}{c}\text { Sum of } \\
\text { Squares }\end{array}$ & df & Mean Square & F & Sig. \\
\hline 1 & Regression & 38.156 & 3 & 12.719 & 27.615 & $.000^{\mathrm{b}}$ \\
\hline & Residual & 15.659 & 34 & .461 & & \\
\hline & Total & 53.816 & 37 & & & \\
\hline
\end{tabular}

a. Dependent Variable: kinerja.pegawai

b. Predictors: (Constant), komitmen, fasilitas, penempatan.kerja 
Pada tabel 5. diatas terlihat bahwa nilai Fhitung adalah 27,615 dan nilai signifikansi 0,000. Diketahui nilai Ftabel dengan tingkat kepercayaan 95\% $(\alpha: 0,05)$ adalah 2,840. Oleh karena itu nilai Fhitung > Ftabel $(27,615$ $>$ 2,840 ) maka $\mathrm{H}_{\mathrm{O}}$ ditolak dan menerima hipotesis dalam penelitian ini yaitu bahwa fasilitas, penempatan kerja dan komitmen secara simultan memiliki pengaruh yang positif dan signifikan terhadap kinerja pegawai Dinas Pangan dan Pertanian Kota Tanjungbalai sebesar 27,615

\subsection{Pengujian Secara Parsial (Uji t)}

Tabel 6. Hasil Uji Parsial Variabel X Terhadap Y

\begin{tabular}{|c|c|c|c|c|c|c|}
\hline \multicolumn{7}{|c|}{ Coefficients $^{\mathrm{a}}$} \\
\hline \multirow{2}{*}{\multicolumn{2}{|c|}{ Model }} & \multicolumn{2}{|c|}{$\begin{array}{l}\text { Unstandardized } \\
\text { Coefficients }\end{array}$} & \multirow{2}{*}{$\begin{array}{c}\text { Standardize } \\
\text { Coefficients } \\
\text { Beta }\end{array}$} & \multirow[t]{2}{*}{$\mathrm{t}$} & \multirow[t]{2}{*}{ Sig. } \\
\hline & & $\mathrm{B}$ & Std. Error & & & \\
\hline \multirow{4}{*}{1} & (Constant) & 5.297 & 4.515 & & 1.173 & .249 \\
\hline & fasilitas & .388 & .102 & 408 & 3.797 & .001 \\
\hline & penempatan.keria & .270 & .092 & .320 & 2.916 & .006 \\
\hline & komitmen & .282 & .100 & .324 & 2.808 & .008 \\
\hline
\end{tabular}

a. Dependent Variable: kinerja.pegawai

\subsubsection{Pengaruh Fasilitas Terhadap Kinerja Pegawai}

Untuk mengetahui secara parsial pengaruh fasilitas terhadap kinerja pegawai dapat dilihat pada tebel 6 diatas. Berdasarkan tabel tersebut diperoleh nilai thitung sebesar 3,797 dan nilai signifikansi 0,001 . Sedangkan nilai tabel pada tingkat kepercayaan 95\% ( $\alpha$ : $0,05)$ adalah 2,021. Oleh karena itu nilai thitung > tabel $(3,797>2,021)$ maka $\mathrm{H}_{\mathrm{O}}$ ditolak dan menerima hipotesis dalam penelitian ini yaitu fasilitas secara parsial berpengaruh positif terhadap kinerja pegawai Dinas Pangan dan Pertanian Kota Tanjungbalai sebesar 3,797.

\subsubsection{Pengaruh Penempatan Kerja} Terhadap Kinerja Pegawai

Untuk mengetahui secara parsial pengaruh penempatan terhadap kinerja pegawai, dapat dilihat pada tebel 6 diatas. Berdasarkan tabel tersebut diperoleh nilai thitung sebesar 2,916 dan nilai signifikansi 0,006 . Sedangkan nilai tabel pada tingkat kepercayaan $95 \%(\alpha: 0,05)$ adalah 2,021. Oleh karena itu nilai thitung > tabel $(2,916>$ 2,021 ) maka $\mathrm{H}_{\mathrm{O}}$ ditolak dan menerima hipotesis dalam penelitian ini yaitu penempatan secara parsial berpengaruh positif terhadap kinerja pegawai Dinas Pangan dan Pertanian Kota Tanjungbalai sebesar 2,916.

\subsubsection{Pengaruh Komitmen Terhadap Kinerja Pegawai}

Untuk mengetahui secara parsial pengaruh komitmen terhadap kinerja pegawai, dapat dilihat pada tebel 6 diatas. Berdasarkan tabel tersebut diperoleh nilai thitung sebesar 2,808 dan nilai signifikansi 0,008 . Sedangkan nilai ttabel pada tingkat kepercayaan 95\% $(\alpha: 0,05)$ adalah 2,021. Oleh karena itu nilai thitung > tabel ( 2,808 > 2,021) maka $\mathrm{H}_{\mathrm{O}}$ ditolak dan menerima hipotesis dalam penelitian ini yaitu variabel komitmen secara parsial berpengaruh positif terhadap kinerja pegawai Dinas Pangan dan Pertanian Kota Tanjungbalai sebesar 2,808.

\subsection{Uji Koefisien Determinasi $\left(\mathbf{R}^{2}\right)$}

Uji determinan adalah uji yang dilakukan untuk mengetahui seberapa besar pengaruh variabel independent terhadap variabel dependent. Untuk melihat hasil uji determinan maka dapat diketahui nili $\mathrm{R}$ Square atau koefesien determinasi dan dapat dilihat dibawah ini.

Tabel 7 Model Summary

\begin{tabular}{|l|r|r|r|r|}
\hline Model & \multicolumn{1}{|c|}{$\mathrm{R}$} & R Square & Adjusted R Square & Std. Error of the Estimate \\
\hline 1 & $.842^{\mathrm{a}}$ & .709 & .683 & .679 \\
\hline
\end{tabular}

Sumber: Out Put SPSS Data Diolah-2020 
Nilai R Square pada tabel 7. diatas adalah 0,709. Dengan demikian bahwa sebesar 70,90\% variabel kinerja pegawai Dinas Pangan dan Pertanian Kota Tanjungbalai sebesar dapat di jelaskan oleh variabel fasilitas, penempatan kerja dan komitmen sedangkan sisanya sebesar $29,10 \%$ di jelaskan oleh variabel lain yang tidak ikut di teliti.

\section{Kesimpulan}

1) Variabel fasilitas secara parsial berpengaruh positif terhadap kinerja pegawai Dinas Pangan dan Pertanian Kota Tanjungbalai

2) Variabel penempatan kerja secara parsial berpengaruh positif terhadap kinerja pegawai Dinas Pangan dan Pertanian Kota Tanjungbalai

3) Variabel komitmen secara parsial berpengaruh positif terhadap kinerja pegawai Dinas Pangan dan Pertanian Kota Tanjungbalai

4) Variabel fasilitas, penempatan kerja dan komitmen secara simultan memiliki pengaruh yang positif dan signifikan terhadap kinerja pegawai Dinas Pangan dan Pertanian Kota Tanjungbalai

\section{DAFTAR PUSTAKA}

Abdul Hameed Aamer Waheed, 2011.

Employee Development and Its Affect on Employee Performance A Conceptual Framework. Employee is a key element of the organization. International Journal of Business and Social Science Vol. 2 No. 13.

Alwi, Safrudin. 2011. Manajemen Sumber Daya Manusia. Yogyakarta: BPFE. Badriyah, Mila. 2015. Manajemen Sumber Daya Manusia. Bandung :CV Pustaka Setia.

Brahmasari, Ida Ayu. 2014. Pengaruh Variabel Budaya Perusahaan Terhadap Komitmen Karyawan dan Kinerja Perusahaan Kelompok Penerbitan Pers Jawa Pos. Surabaya: Disertasi Universitas Airlangga.

Cash, W.H. and F.E. Fischer. 2010. Human Resource Planning. Dalam Famularo, J.J., Hand Book of Human Resources Administration (hlm 10.310.20). Singapore: Fong and Sons Printers Pte Ltd.
Djojowirono. 2015. Manajemen Sumber daya Manusia, Edisi Keempat, Teknik Sipil UGM, Yogyakarta.

Fadel, Muhammad. 2014. Reinventing Local Government. Jakarta: PT. Elex Media Komputindo.

Faisal, Mohammad Amir. 2015. Memahami Evaluasi Kinerja Karyawan, Konsep, dan Penilaian Kinerja di Perusahaan. Jakarta: Mitra WacanaMedia.

Gaol, CHR. Jimmy L. 2014. A to Z Human Capital (Manajemen Sumber Daya Manusia) Konsep, Teori, dan Pengembangan dalam Konteks Organisasi Publik dan Bisnis. Jakarta: PT. Gramedia Widiasarana.

Gomes, Faustino Cardoso. 2013. Manajemen Kinerja. Yogyakarta: Andi Ofset. Greenberg, J. 2015. Behaviour in Organizations: Understanding and

Managing The Human Side of Work, Third Edition. Massachuscets: Allin and Bacon.

Griffin, Ricky W., and Moorhead, Gregory., 2014. Organizational Behavior: Managing People and Organizations. Eleventh Edition. USA: South Western.

Hariandja, Marihot Tua Efendi. 2012. Manajemen Sumber Daya Manusia. Jakarta : Grasindo.

Hartanto, R. D. 2015. Pengaruh Komunikasi, Kepemimpinan dan Budaya Organisasi terhadap Kinerja karyawan Pada PDAM Kabupaten Demak. Semarang: Fakultas Ekonomi Universitas Stikubank.

$\begin{array}{crrr}\text { Teori } & 2010 . & \text { Organisasi } & \text { Perusahaan } \\ \text { Struktur dan } & \text { Perilaku. }\end{array}$ Yogyakarta: BPFE.

Hartatik, Indah Puji. 2014. Buku Praktis Mengembangkan Sumber Daya Manusia. Yokyakarta: Laksana.

Hasibuan, Malayu S.P. 2012. Manajemen Dasar Pengertian dan Masalah. Jakarta: Bumi Akasara.

2015. Organisasi dan Motivasi. Jakarta: Bumi Akasara. Husnan, Saud. 2012. Manajemen Personalia. Yogyakarta: BPFE UGM.

I Made Bagus Githa Wijaya,I Wayan Suana. 2011. Pengaruh Penempatan Dan komitmen Terhadap Kepuasan Dan Kinerja Karyawan (study pada karyawanfood and beverage service). Jurnal.

Jannah, Lina Miftahul. 2018. Metode Penelitian Kuantitatif Teori dan 
Aplikasi. Jakarta : Pt. Raja Grafindo Persada.

Komang Elsy Yunita, Ni Nyoman Yulianthini, I Wayan Bagia. 2013. Pengaruh Pengalaman Kerja Dan Penempatan Karyawan Terhadap Kinerja Karyawan (objek pada karyawan Bali Taman Lovina Resort \& SPA). Jurnal.

Lukiyana, Sriyanto. 2013. Pengaruh fasilitas

Dan komitmen Terhadap kinerja Karyawan Dengan Penempatan Kerja Sebagai Variabel Intervening (Studi Pada Karyawan Universitas 17 Agustus 1945 Jakarta). Tesis.

Lupiyoadi, Rambat. 2016. Manajemen Pemasaran Jasa. Edisi 2. Jakarta: Penerbit Salemba Empat.

Luthans, Fred. 2015.

Organizational Behavior; An Evidence-Based Approach, 13th Ed, 13 th Edition, Alih Bahasa Vivi Andika Yuwono dkk, Andi, Yogyakarta.

Mahsun, Mohamad. 2016. Pengukuran Kinerja Sektor Publik, Cetakan Pertama. Yogyakarta: BPFE.

Mangkuprawira, Sjafri. 2011. Manajemen Sumber Daya Manusia Strategik. Bogor: Ghalia Indonesia.

$$
\text { 2012. Strategi Efektif }
$$

Mengelola Karyawan. Bogor: Ghalia Indonesia.

Marwansyah. 2010. Manajemen Sumber Daya Manusia. Bandung: Alfabeta. Mathis, Robert L. dan Jackson, John H. 2011. Manajemen Sumber Daya

Manusia Edisi 9, dialih bahasakan oleh Jimmy Sadeli dan Bayu Prawira Hie. Jakarta: Salemba Empat.

Nitisemito, Alex S. 2011. Manajemen Personalia. Jakarta: Ghalia Indonesia. Pasolong, Harbani. 2010. Teori Administrasi Publik. Bandung: Alfabeta. Prawira, Sentono. 2011. Manajemen Produktivitas. Jakarta: Bumi Aksara.

Purwaningsih, Ratna. 2018. Manajemen Sumber Daya Manusia. Bandung : PT. Refika Aditama.

Riduan. 2017. Aplikasi Statistika dan Metode Penelitian Untuk Administrasi dan Manajemen. Bandung: Dewa Ruci.

Riva'i, Veithzal. 2014. Kepemimpinan dan Perilaku Organisasi. Jakarta: PT. Raja Grafindo Persada.
2015. Manajemen Sumber Daya Manusia Untuk Perusahaan. Jakarta: PT. Raja Grafindo Persada.

Robbins, Stephen P. 2015. Perilaku Organisasi. Jakarta: Salemba Empat.

Santoso, Singgih. 2014. Mengatasi Berbagai Masalah Statistik dengan SPSS Versi 11.5. Jakarta: Elex Media Komputindo.

Setiyawan, Ade. 2015. Metodologi Penelitian Manajemen Sumber Daya Manusia. Jakarta : PT. Raja Grafindo Persada.

Siagian, Sondang P. 2010. Teori dan Praktek Kepemimpinan. Jakarta: CV Haji Mas Agung.

Simamora, Henry. 2012. Manajemen Sumber Daya Manusia. Edisi 1. Yogyakarta: STIE YKPN Yogyakarta. 2014. Akuntansi Manajemen. Yogyakarta: STIE YKPN Yogyakarta.

Simanjuntak, Payaman J. 2015. Manajemen Evaluasi Kinerja, Edisi 3. Jakarta: Fakultas UI.

Soekidjan. 2009. Manajemen Sumber Daya Manusia. Jakarta: Bumi Aksara. Sofyan, Hanafi. 2011. Manajemen Sumber Daya Manusia. Jakarta: Elex Media Komputindo.

Sopiah. 2018. Perilaku Organisasi. Yogyakarta : Andi.

Sugiyono. 2013. Metode Penelitian Bisnis, Cetakan kesembilan. Bandung: Alfabeta.

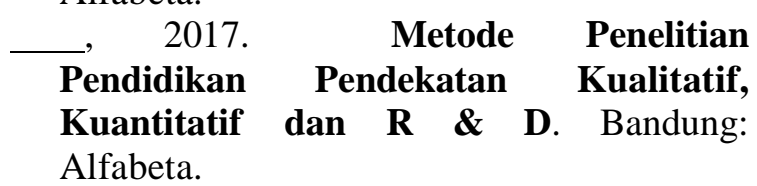

Suharyadi. 2016. Statistika Untuk Ekonomi Dan Keuangan Modern Edisi 2 Buku 2. Jakarta: Salemba Empat.

Sutiadi, 2013. Motivasi Karyawan Dan Aktifitas Manajerial Kepemimpinan Terhadap Kinerja Karyawan Pasca Sarjana Universitas Brawijaya Malang. Jurnal.

Tika H. Moh. Pabundu. 2016. Budaya Organisasi dan Peningkatan Kinerja

Perusahaan, Cetakan Pertama. Jakarta: PT. Bhumi Aksara. Trenggono. 2018. Metode Penelitian Manajemen. Jakarta: Rajawali Pers. Triatna,Cepi. 2015. Perilaku Organisasi. Bandung: PT.Remaja Rosdakarya. 
Triton, PB. 2016. Manajemen Sumber Daya Manusia: Perspektif Partnership dan Kolektivitas. Yogyakarta: Tugu.

Wahyudi, Bambang. 2012. Manajemen SUmber Daya Manusia. Bandung: Sulita.

Yehezkiel Tambayong, Joost Rumampuk, Billy Kountul. 2010. Hubungan Penempatan Pegawai Dengan kinerja Kerja Pegawai PadaYayasan Dharma Bhakti Indonesia Tomohon. Jurnal.

Yuyun Yuniasih. 2015. Pengaruh fasilitas

Dan Komunikasi Terhadap Kinerja Karyawan (Suatu Penelitian Pada Staff Pegawai Non Manajer Di Bank Tabungan Pensiun Nasional Tbk. Kota Tasikmalaya). Jurnal. 